\title{
1 Morphological facilitators for vocal learning explored through the syrinx anatomy of a
}

\section{2 basal hummingbird}

3 Amanda Monte ${ }^{1}$, Alexander F. Cerwenka ${ }^{2}$, Bernhard Ruthensteiner ${ }^{2}$, Manfred Gahr ${ }^{1}$, and

4 Daniel N. Düring ${ }^{1,3,4 *}$

$5 \quad *$ Correspondence: dduering @ethz.ch

61 - Department of Behavioural Neurobiology, Max Planck Institute for Ornithology,

7 Seewiesen, Germany

82 - SNSB-Bavarian State Collection of Zoology, Munich, Germany

93 - Institute of Neuroinformatics, ETH Zurich \& University of Zurich, Zurich, Switzerland

104 - Neuroscience Center Zurich (ZNZ), Zurich, Switzerland

\section{Abstract}

12 Vocal learning is a rare evolutionary trait that evolved independently in three avian clades:

13 songbirds, parrots, and hummingbirds. Although the anatomy and mechanisms of sound

14 production in songbirds are well understood, little is known about the hummingbird's vocal

15 anatomy. We use high-resolution micro-computed tomography $(\mu \mathrm{CT})$ and microdissection to

16 reveal the three-dimensional structure of the syrinx, the vocal organ of the black jacobin

17 (Florisuga fusca), a phylogenetically basal hummingbird species. We identify three unique

18 features of the black jacobin's syrinx: (i) a shift in the position of the syrinx to the outside of

19 the thoracic cavity and the related loss of the sterno-tracheal muscle, (ii) complex intrinsic

20 musculature, oriented dorso-ventrally, and (iii) ossicles embedded in the medial vibratory

21 membranes. Their syrinx morphology allows vibratory decoupling, precise control of 
22 complex acoustic parameters, and a large redundant acoustic space that may be key

23 biomechanical factors facilitating the occurrence of vocal production learning.

24 Keywords: black jacobin, vocal production, musculus sternotrachealis (ST), vibrato,

25 evolution 


\section{Introduction}

Vocal learning in birds -- the rare ability to acquire new sounds from the environment -holds striking parallels with speech acquisition in humans (Marler, 1970). Vocal learning evolved independently in songbirds (suborder Oscines) (Bottjer et al., 1985; Nottebohm et al., 1976), parrots (order Psittaciformes) (Jarvis and Mello, 2000) and hummingbirds (family

Trochilidae) (Baptista and Schuchmann, 1990) due to convergent neurological shifts (Jarvis, 2007). Thus, the brains of avian vocal learners are uniquely specialized, unlike non-vocallearner species, to perceive, produce and memorize sounds (Gahr, 2000; Nottebohm et al., 1976; Paton et al., 1981). However, the pressures underlying this independent convergence remain unknown and attempts to explain the evolution of vocal learning face challenges from the divergences in the life histories of the vocal learners (Jarvis, 2006; Nowicki and Searcy, 2014).

Efforts to understand vocal learning have concentrated on the neural processes that modulate vocal output with little regard to the integral part given by the biomechanics of sound production in the vocal organ (Düring and Elemans, 2016). The vocal organ in birds is the syrinx (Clarke et al., 2016; King, 1989), an avian novelty optimized for birds' particularly long air tracts (Riede et al., 2019). The syrinx is located where the trachea bifurcates into the bronchi and is suspended inside the interclavicular air sac (King, 1989). One or two pairs of vibrating tissues are present; depending on where these tissues are located, the syrinx can be classified as tracheal, tracheobronchial or bronchial (Smolker, 1947). The syrinx musculature is of two basic types: extrinsic musculature, which is attached outside of the syrinx at one end, and intrinsic musculature, which is attached to the syrinx at both ends (Ames, 1971; Gaunt and Gaunt, 1985). While every bird has extrinsic musculature, 
52 birds (Ames, 1971; King, 1989). For example, gallinaceous species have none, songbird species have from three to five intrinsic muscle pairs (Ames, 1971; Gaunt, 1983), while parrot species mainly have two (Gaunt, 1983; Nottebohm, 1976).

Syrinx anatomy, in general, is highly variable among and consistent within higherlevel taxa, to the extent that syrinxes have been used as a taxonomic tool for avian phylogenetic classification (Ames, 1971; Düring and Elemans, 2016; Suthers and Zollinger, 2008). Similarities in gross morphology and its implications for vocal production may help us to understand the morphological basis of vocal learning (Elemans et al., 2015; Gaunt, 1983). Thus, the presence of intrinsic musculature has been hypothesized as a prerequisite and not an adaptation for vocal learning (Gaunt, 1983; Mindlin and Laje, 2006), that is, all vocal learners should have intrinsic muscles, but not all species that have intrinsic muscles are vocal learners. Unlike extrinsic muscles, which move the syrinx as a unit (Gaunt, 1983; Mindlin and Laje, 2006), intrinsic muscles dissociate the control of tension from the control of amplitude, for example, which in turn affects pitch (Düring et al., 2017; Goller and Riede, 2013).

Recent studies indicate that musculature is just one of the variables that define the multi-dimensional parameter space that translates motor commands into vocal output (Amador and Mindlin, 2008; Düring et al., 2017; Düring and Elemans, 2016; Elemans et al., 2015). Many factors, such as syrinx's morphology, physical interaction with the surrounding environment, and neuro-mechanic activity, contribute to the creation of a large acoustic space that is highly redundant (Elemans et al., 2015). This redundancy allows specific vocal 73 parameters, such as pitch, to be achieved by multiple combinations of, for example, expiratory air pressure and muscle activity (Elemans et al., 2015). The availability of multiple 
76 process and is hypothesized as necessary for the development of vocal learning (Elemans et 77 al., 2015).

To approach vocal learning from the biomechanical perspective, the syrinxes of vocal learners need to be systematically compared. Among avian vocal learners, hummingbirds are the most basal taxon and phylogenetic distant from parrots and songbirds (Baptista and Schuchmann, 1990; Gahr, 2000; Jarvis et al., 2000; Prum et al., 2015), and the only group in which not all species have the ability of vocal learning (Gahr, 2000; Williams and Houtman, 2008). The acoustic features of their vocalizations vary substantially within the group (Ferreira et al., 2006; Ficken et al., 2000), ranging from simple vocalizations to acoustic performances that are above the known perceptual limits of birds (Duque et al., 2018; Olson et al., 2018). Currently, we lack a detailed description of the hummingbird syrinx and, therefore, insights into the biomechanics of hummingbirds' peculiar vocalizations. detailed structure of both skeletal elements and vibratory soft tissues of the black jacobin (Florisuga fusca) syrinx. The black jacobin belongs to the clade Topaze (subfamily Topazini), the most basal among hummingbirds (McGuire et al., 2014). It can vocalize on high F0 with harmonics over the human audible range (Olson et al., 2018). Our results provide fundamental insights into the biomechanics of sound production in hummingbirds and the anatomical factors driving or facilitating the emergence of vocal learning in birds.

\section{Results}

\section{General anatomy of the black jacobin's syrinx}

98 The black jacobin has a tracheobronchial syrinx that is located where the trachea bifurcates

99 into the two primary bronchi, approximately $9.4 \mathrm{~mm}$ far from the heart and outside of the 
100 thoracic cavity. The trachea is a long, funnel-shaped tube that extends along the cervical

101 column whose diameter is reduced to around $1 / 4$ of its original size when proximal to the

102 syrinx. From the syrinx on, the bronchi run parallel for about $1.3 \mathrm{~mm}$, separating when inside

103 the thorax. Parts of the trachea and bronchi, and the syrinx, are tightly packed by a multi-

104 layered membrane, most likely an evagination of the clavicular air sac membrane (Zusi, 105 2013).

107 The syringeal skeleton of the black jacobin

108 The syringeal skeleton of the black jacobin is composed of cartilaginous tracheal rings, a 109 solid tympanum and modified bronchial half-rings, two of which are partially ossified (Fig.

$1101 \mathrm{~A}$ and $1 \mathrm{C}$ ). The trachea consists of complete cartilaginous rings ( $\mathrm{T} 1$ to $\mathrm{Tn}$ ), each of which is 111 thinner in its dorsal part and wider towards the tympanum. The tympanum is a cylindrical

112 bone likely formed by the fusion of tracheal and bronchial rings; this fusion forms the 113 tympanum in other tracheobronchial syrinxes, for example, that of the zebra finch syrinx 114 (Düring et al., 2013). Internally, the tympanum body is a relatively uniform tube with an 115 ossified lamella in its caudal part that projects medially into the air passage. Externally, the 116 ventral part of the tympanum body presents a squared expansion that, together with the

117 internal lamella, constitutes the pessulus. The pessulus separates a symmetrical pair of 118 horizontal ridges that delimit medially the two main craniocaudal concavities to which 119 muscles are attached (Fig. 1B). The U-shaped dorsal part of the tympanum is formed by two 120 solid expansions in each of the lateral caudal edges and a medial concavity that extends 121 horizontally along the entire surface as a muscle attachment site. In the caudomedial part, a 122 pair of rounded bones, the tympanic ossicles (ossicula tympanica), are embedded in an 123 extension of the most medial part of the vibratory tissues (Fig. 1D). 

mm, until reaching the lungs. Only the first two pairs are partially ossified (B1 and B2); the others are cartilaginous. The first pairs (B1 to B3) are highly modified compared to the other bronchial half-rings (Fig. 1A and 1B). Each ring of the B1 pair is composed of a ventral

128 spherical ossification, and a cartilaginous arc projects both dorsally along the caudal part of

129 the tympanum and caudally in relation to the B2 pair. This pair is located in the dorsal part of

130 the syrinx, in a transverse plane, each of which has round edges and a concavity towards the

131 ventro-lateral part of the syrinx; a cartilaginous projection extends in the same shape into the

132 caudal direction, almost reaching the B1 cartilaginous arc. Each of the B3 pairs is a 133 cartilaginous arc-shaped half-ring whose concavity extends toward the lumen of the 134 bronchus. Slightly medial in relation to the B1 arc, each pair has ventral and dorsal extremities that serve as attachments for one of the vibratory membranes.

137 The syringeal muscles of the black jacobin

138 All syringeal muscles of the black jacobin are paired (Fig. 2). There is one pair of extrinsic,

139 the musculus tracheolateralis (tracheolateral muscle; TL) and at least three pairs of intrinsic 140 syringeal muscles: musculus syringealis cranialis dorsalis ventralis (ventro-dorsal cranial 141 syringeal muscle; VDCrS), musculus syringealis lateralis dorsalis ventralis (ventro-dorsal 142 lateral syringeal muscle; VDLS), and musculus syringealis caudalis dorsalis ventralis 143 (ventro-dorsal caudal syringeal muscle; VDCaS).

145 cranial part of the trachea and extended caudally alongside the muscle's lateral part until 146 reaching the latero-cranial extremity of the tympanum (Fig. 2E-2G). 
All intrinsic muscles are oriented ventro-dorsal. They attach ventrally to the tympanum and dorsally to some of the modified bronchial half rings. The VDCrS, the largest muscle, is responsible for $54 \%$ of the intrinsic musculature volume and follows the typical

150 cardioid contour of the dorsal syringeal surface (Fig. 2C and 2D). The VDCrS caudal 151 attachment site is in the ventrocranial head of the modified bronchial half-ring B2. A few 152 muscle fibers of the VDCrS are attached via connective tissue to the tympanic ossicles. The VDLS comprises $34 \%$ of the intrinsic musculature volume placed mainly in the lateral part of the syrinx (Fig. 2F). The caudal attachment site of the VDLS is located on the lateral extent of half-ring B2 and includes its cartilaginous expansion. The VDCaS makes up the remaining $12 \%$ of the intrinsic musculature volume and runs mainly ventrally (Fig. $2 \mathrm{~A}$ and $2 \mathrm{~B}$ ). The attachment sites of the VDCaS are located at the most caudal concavities of the pessulus and along the lateral outline of the cartilaginous extension of the half-ring B1.

Vibratory tissue of the black jacobin's syrinx

The syringeal vibratory tissues are composed of a pair of lateral labia (LL), each labium located in the lateral part of each side of the syrinx, and a pair of medial labia (ML) that continue into the medial tympaniform membrane (MTM). ML and MTM form the medial vibratory mass (MVM) in the medial part of the syrinx caudal to the tympanum (Fig. 3A). The LL is placed parallel to the ML and extends cranially over the tympanic lumen and caudally among the half-rings B1 to B3 (Fig. 3A). The LL has $45 \%$ of the volume of the ML and is ventrally attached to the pessulus, dorsally to B2 and laterally to the medial part of the B1 (Fig. 3A). The MVM constitutes a continuous mass of vibratory tissue reduced to $39 \%$ in thickness from the cranially located ML to the MTM. The ML is cranioventrally attached to

170 the pessulus and dorsally attached to the half-ring B2. In the craniodorsal part, the ML 171 thickens nearly 5-fold in an extension that embeds the tympanic ossicles and projects to the 
172 air passage (Fig. 3B and 3C). This extension, which comprises $37 \%$ of the total volume of

173 ML and the tympanic ossicles comprise a further $6 \%$, connects to a muscle via a thin

174 ligament such as was reported previously for hummingbirds (Zusi, 2013). The MTM is

175 ventro-dorsally attached to the medial edges of the bronchial half-ring B3.

177 Biomechanics of the black jacobin's syrinx

178 To explore potential general mechanisms of adduction, abduction, and stretching of the sound-producing elements, we carefully fixed one-half of the syrinx under a microscope and

180 manually actuated the musculature around the ML in vitro. We identified the mechanism, 181 which in sequential muscle activation, seems responsible for the adduction of the LL and 182 stretching of the ML and LL. Applying an increasing amount of force to the caudal part of the 183 cartilaginous arc extending from B1, the attachment site of VDCaS, resulted in an inward 184 rotation of B1 and caused first partial and then complete adduction of the LL. A craniad force 185 applied on the head of the B2, the attachment site of the VDCrS, resulted in the dorso-ventral 186 stretching of the ML and LL (Fig. 4A). Considering the anatomical disposition of the VDLS, 187 a lateral force applied on the lateral part of the B2, the attachment site of VDLS, may result in 188 outward rotation of the B2 and cause the abduction of the ML. Thus, each of the three 189 intrinsic muscles seems to be involved in one of the main tasks controlling sound production 190 in the syrinx: the VDCaS on adduction, which closes the bronchial lumen; the VDLS on 191 abduction, which opens the bronchial lumen; and the VDCrS, which controls the tension of 192 ML and LL (Fig. 4B). 
194 Spectral analysis of the black jacobin's vocalization

195 The black jacobin vocalizes with a fundamental frequency (F0) that ranges from 1.8 to 11.8

$196 \mathrm{kHz}(\mathrm{n}=105$ recordings with a total of 1242 motor units, so-called syllables). We identified

197 three types of vocalizations with distinct spectral structure: low-pitched vocalization with an

198 F0 average of $1.8 \mathrm{kHz}( \pm 0.5, \mathrm{n}=66$ syllables $)$; click-like chirps with an F0 average of 7.9

$199 \mathrm{kHz}( \pm 1, \mathrm{n}=148$ syllables); and high-pitched vibratos with an F0 average of $11.8 \mathrm{kHz}( \pm$

$200 \quad 0.4, \mathrm{n}=1028$ syllables) (Fig. 5A).

The black jacobin's most frequent type of vocalization is the high-pitched vibrato composed of syllables repeated in groups with up to three repetitions; the vibrato has a fundamental frequency of around $12 \mathrm{kHz}$ with harmonics reaching the ultrasonic range of humans (this study; Olson et al., 2018). Each vibrato syllable is composed of fast oscillations with periodic changes of the fundamental frequency (Fig. 5B) and an average duration of $95.8 \pm 35 \mathrm{~ms}(\mathrm{n}=18$ syllables). Within a syllable, the difference between the highest and the lowest modulation of frequency, known as the vibrato extent, ranged from 0.7 to $3 \mathrm{kHz}$ (average $1.5 \pm 0.5 \mathrm{kHz}, \mathrm{n}=401$ crest-trough pairs, Fig. 5B) with a periodicity of around 2.4 ms $( \pm 1.4 \mathrm{~ms}, \mathrm{n}=401)$. Thus, the black jacobin can produce syllables that change their

210 fundamental frequency at an average rate of $233.2 \mathrm{~Hz}( \pm 37.5, \mathrm{n}=18$ syllables $)$. For example,

211 Whitney Houston produced an average vibrato rate of $5.1 \mathrm{~Hz}( \pm 0.6, \mathrm{n}=12$ vibratos $)$ with a

212 vibrato extent of $0.05 \mathrm{kHz}( \pm 0.01)$ (Fig. 5C). This means black jacobin's vibrato rate 213 surpasses that of a human singer by more than 45 -fold. Within birds, vibratos are reported to 214 be produced by only a few species (Ferreira et al., 2006; Mundinger, 1995), but no 215 quantification of vibrato rate or extent is available. For comparison, we quantified the vibrato 216 rate of a songbird, Eurasian skylark (Alauda arvensis). The skylark's vibrato rate is almost 217 17-fold higher than that of a human singer, with an average of $89.7 \mathrm{~Hz}( \pm 14.4, \mathrm{n}=10$ 218 syllables), and the vibrato extent averaged 8-fold larger, $0.4 \mathrm{kHz}( \pm 0.02)$ (see Methods for 
219 details). No vibrato reported to date combines such a fast rate and wide extent as that of the black jacobin (Fig. 5C).

\section{Discussion}

223 Here we present the first detailed description of the vocal tract of a basal hummingbird species, a species with the potential to illuminate how vocal learning has evolved. We identified the presence of heavily modified bones, intrinsic syringeal musculature with a particular orientation and a pair of vibratory tissues in each of the sides of the syrinx, each of which contains an ossified structure. This peculiar syringeal morphology allows the black jacobin to produce a vibrato that challenges the known limits of this acoustic feature.

231 The black jacobin's syrinx is located outside of the thoracic cavity, in contrast to songbirds 232 and parrots that have their syrinxes inside the thoracic cavity (Ames, 1971). Hummingbirds 233 are highly specialized for hovering: unsurprisingly, its flight muscles make up 25 to $30 \%$ of 234 its body weight, a ratio that is more than that of any other bird family (Schuchmann, 1999).

235 The hummingbird's enlarged flight muscles are combined with an enlarged heart, comprising 236 about $2.5 \%$ of its body mass. The syrinx location outside of the thoracic cavity potentially 237 alleviates spatial constraints and avoids mechanical disturbances from the enlarged flight or 238 cardiac muscles. Since this syrinx displacement was reported in a few species of derived hummingbird sub-families (Beddard, 1898; Müller, 1878; Zusi, 2013), its occurrence in the 
241 allowed the hummingbird to evolve control over its syringeal biomechanics by decoupling them from the harsh environment of internal organs.

In songbirds, the decoupling from internal organs is achieved through the sternotracheal muscle (ST), which is thought to stabilize the syrinx in most birds including the songbirds (Düring and Elemans, 2016; Suthers, 2004; Suthers and Zollinger, 2008). Black jacobins lack the ST altogether but seem to have further refined syrinx stabilization through tight wrapping of the syrinx in several layers of soft tissue. These layers create a rigid frame, protecting the syrinx from its immediate environment while keeping the syringeal elements inside flexible and maintaining the differential pressure necessary for the onset of sound production (Elemans et al., 2015; Gaunt and Gaunt, 1985). The most external of these layers might be an evagination of the interclavicular membrane that cranially encloses the syrinx within the interclavicular air sac, which has also been reported in other hummingbird species (Zusi, 2013).

In non-passerines, the ST is also involved in sound production. For example in the tracheal syrinx of pigeons, the shortening of the ST brings its cartilages closer together, thereby closing the syringeal lumen (Mindlin and Laje, 2006). The adduction of the labia is crucial for sound production in general as it allows to build up the phonation threshold pressure (PTP), which is necessary for sound onset (Titze, 1992). In songbirds, adduction is achieved by intrinsic musculature, rather than ST adduction (Elemans et al., 2015) Similarly,

260 due to the lack of ST muscles, the closing mechanism in black jacobins is operated by 261 intrinsic musculature. intrinsic muscles of the black jacobin's syrinx are oriented dorso-ventrally, likely a synapomorphy of hummingbirds, while the intrinsic muscule fibers of most bird taxa run 
cranio-caudally (King, 1989; Smolker, 1947). Because all of the black jacobin's intrinsic muscles are ventrally attached to the tympanum, but each of them is dorsally attached to a different point, they run dorso-ventrally on different angles. The general dorso-ventral orientation with differences in angulation might allow the black jacobin to control the mobile syringeal elements despite the lack of lateral stabilization provided by the STs in other taxa. hummingbirds (Müller, 1878), might have been one of the driving pressures for the evolution of intrinsic muscles, a key prerequisite of vocal learning.

Tympanic ossicles

275 Although cartilaginous formations were found embedded in the vibrating tissues of songbirds 276 (Düring et al., 2013), tympanic ossicles have not been reported in any species other than 277 hummingbirds (Müller, 1878; Zusi, 2013). The origin of tympanic ossicles is uncertain. Due to their medial position and proximity to the tympanum, they might be either modified bronchial half-rings or have originated from a tracheal ring. In humans, the prevalence of a

280 small sesamoid bone in the knee has increased worldwide in the past century, probably as a dissipative response to increased mechanical forces due to the enlargement of leg bones and muscles (Berthaume et al., 2019). Similarly, increased tension in the labia might have led to the formation of tympanic ossicles in the black jacobin's syrinx. properties of the tissue itself (Düring et al., 2017; Riede et al., 2010). In songbirds, cartilage embedded in the medial labia (ML) both aids in the dissipation of the tension, avoiding

287 rupture under high stress and modifies the elastic properties of the syrinx (Düring et al., 
gradual bending mechanism, which in turn allows uncoupling the control of amplitude and frequency (Düring et al., 2013). Similarly, this might be the function of the cartilaginous extension in the dorsal part of the ML and its embedded ossicles, the tympanic ossicles, in the black jacobin. This extension is connected by a thin strip of connective tissue to a few muscle fibers of the larger syringeal muscle; given this arrangement, direct muscular control of the extension seems likely.

The tympanic ossicles may contribute to achieving the black jacobin's high fundamental frequency: they cause high local density and prevent an entire part of the ML from vibrating at all, thus shortening its length and increasing the fundamental frequency. In other words, the tympanic ossicles could be used as a secondary mechanism to gradually increase ML stiffness and reduce ML length. It is therefore likely that the cartilaginous extension of the ML in the black jacobin both shifted the elastic properties of the ML towards the optimal for high fundamental frequency by increasing ML density towards the muscle attachment site that directly controls ML stiffness, and shortened the vibratory part of the ML.

\section{Extreme vocal performance}

306 Black jacobins produce particularly rapidly-modulated vibrato sounds (this study; Olson et 307 al., 2018). The black jacobins' vibratos oscillate periodically up and down with a frequency bandwidth of up to $3 \mathrm{kHz}$ at a rate of about $250 \mathrm{~Hz}$. This fast vibrato rate can be compared to that of other extreme vocal performances, such as of starlings (Sturnus vulgaris), a songbird

310 whose muscle activity in the syrinx produces changes in sound amplitude at a repetition rate 311 of $218 \mathrm{~Hz}$ (Elemans et al., 2008). The musculature of the songbird's syrinx belongs to a 
313 can produce work at cycling limits of approximately $90 \mathrm{~Hz}$ to $250 \mathrm{~Hz}$ (Rome et al., 1996). In

314 vitro preparations revealed that the superfast songbird muscles in the syrinx have the

315 potential to function at cycle frequencies as fast as $250 \mathrm{~Hz}$ (Elemans et al., 2008). Although

316 direct electromyographic recordings of the syringeal musculature would be needed to confirm

317 that the black jacobin's vibrato rate of $250 \mathrm{~Hz}$ is a direct result of muscular control, this

318 extremely fast performance suggests that the black jacobin's syringeal muscles produce work

319 on the upper limit of the superfast muscle activity reported to date (Elemans et al., 2008) and

320 that black jacobins may have muscle properties comparable to those of songbirds.

322 Biomechanics of sound production and implications for vocal learning in hummingbirds

323 Parrots and songbirds, two vocal learners, have a tracheal and a tracheobronchial syrinx, respectively, both with intrinsic musculature (Ames, 1971; Düring et al., 2013; Gaban-Lima and Höfling, 2006; Nottebohm, 1976). The black jacobin's syrinx, like that of all the other hummingbird species reported so far (Müller, 1878; Zusi, 2013), is tracheobronchial, with three pairs of intrinsic muscles that are as complex as those of songbirds. The black jacobin's multiple intrinsic muscles attach in close proximity to movable elements of its syringeal skeleton (modified bronchial bones) to which the vibrating tissues (medial labia or lateral labia) are attached via cartilaginous extensions. These muscles seem to operate constitutively.

331 For example, both lateral and medial labia are attached to the bronchial half-ring B2, where

332 two large muscles are attached. At its cranial surface is the ventro-dorsal cranial syringeal 333 muscle (VDCrS), and at its lateral part, the ventro-dorsal lateral syringeal muscle (VDLS).

334 Various amounts of contraction of each muscle might contribute gradually to distinct 335 functions, such as the abduction of the ML and the stretching of the labia. Since position and 336 tension of the labia are directly related to distinct acoustic parameters, multiple muscles 337 contributing to the same function creates redundancy in possible motor commands 
338 controlling accoustic parameters such as pitch. When the brain has multiple, rather than a

339 unique, motor command available to achieve a certain vocal output, a redundant control

340 space may simplify trial-and-error attempts during imitation in the vocal production learning

341 process (Elemans et al., 2015).

\section{Conclusion}

344 Here we present the first high-resolution morphology of a hummingbird syrinx, the black 345 jacobin's. We suggest the absence of sternotracheal muscle, presence of tympanic ossicles, 346 dorso-ventral muscle orientation and syringeal displacement as synapomorphies within 347 hummingbirds. These characteristics might have evolved concomitantly with the 348 displacement of the syrinx out of the thorax, as an operational solution to reduce interference

349 of the syrinx with the enlarged heart and flight muscles. The biophysical and biomechanical 350 redundancies emerging from the hummingbird's syrinx morphology may represent a crucial 351 step towards the evolution of vocal learning in hummingbirds.

\section{Methods}

$\underline{\text { Tissue collection and preparation }}$

354 The black jacobins $(\mathrm{n}=3$ ) were captured with a hummingbird-specific "Ruschi trap" (Ruschi, 2009) in the park of the National Institute of the Atlantic Forest (former Professor Mello Leitão Museum), Espírito Santo State, Brazil, in accordance with the Brazilian Institute of

357 Environment and Renewable Natural (IBAMA) regulations under the Biodiversity 358 Information and Authorization System (SISBIO) license number 41794-2.

Two males were deeply anesthetized with ketamin $(15 \mathrm{mg} / \mathrm{kg})$ and perfused through a

360 cardiac injection with the following sequence of solutions: $0.5 \mathrm{ml}$ heparin-nautriun 
anticoagulant, 0.9 saline buffer and $4 \%$ paraformaldehyde fixative. After the perfusion, the syrinx was dissected and stored in the fixative for 24 hours and then stored in $0.1 \mathrm{M}$ phosphate-buffered saline (PBS) in solution with $0.05 \%$ sodium acid until use. We used both fixed syrinxes for micro-computed tomography, one stained for the visualization of soft tissues and the other without the staining procedure for clear visibility of the ossified structures. Both syrinxes were dissected with a large part of the esophagus and bronchi as close as possible to the beak and lungs, respectively, to access the syrinx structures integrally. A third male black jacobin was killed with an anesthetic overdose and the syrinx immediately dissected and cryopreserved at $-80{ }^{\circ} \mathrm{C}$ until use. This syrinx was micro-dissected.

\section{Micro-dissection}

372 The cryopreserved syrinx was thawed gradually. First, at $-20{ }^{\circ} \mathrm{C}$ for one hour followed by 24 ${ }^{\circ} \mathrm{C}$ during the time of manipulation. For manipulation, the syrinx was pinned down on a glass Petri dish covered by black dissecting pan wax and filled with 0.1 M PBS. We disassembled the syrinx under an MZ75 stereomicroscope (Leica Microsystems, Germany) equipped with an ISH500 5.0 MP camera (Tucsen Photonics, China).

The syrinx was inspected ventrally and dorsally; the main musculature and ossifications matched with the $\mu \mathrm{CT}$-based reconstitution. The difference in the density of adjacent soft tissues was noted by a comparison of their light reflection. We sectioned the muscles at their tympanic insertion site and noted the general orientation of fibers. We repositioned the syrinx caudally, centering it where the bronchia bifurcated, with bronchi angled at $180^{\circ}$ exposing the vibratory tissues. The mobile structures in which the vibratory tissue was attached were noted. With a pin, we applied gentle force to each of these mobile structures and photographed the effect of the applied force on the vibratory tissue. 


\section{Micro-computed tomography}

387 The micro-computed tomography $(\mu \mathrm{CT})$ scans of isolated syrinxes (two males) was conducted at the Zoologische Staatssammlung München (Munich, Germany) using a phoenix with down to $3.1 \mu \mathrm{m}$ voxel size.

One syrinx was scanned without staining to access the anatomy of the ossified $\mu \mathrm{A}$ source current, $0.1 \mathrm{~mm}$ aluminum filter, $500 \mathrm{~ms}$ exposure time, $3.1 \mu \mathrm{m}$ isotropic voxel resolution, 1000 projections over $360^{\circ}$ with three averaged images per rotation position, and a

395 total of 132 min scan time, using a molybdenum target. The second syrinx was stained with a contrast agent to image soft tissues. It was placed inside a glass vial with $0.1 \%$ Lugol's solution (Sigma Aldrich). The vial was placed on a tube roller for $48 \mathrm{~h}$. The stained syrinx was scanned for 48 minutes using the following parameters: $80 \mathrm{kV}$ source voltage, $180 \mu \mathrm{A}$ source current, $0.1 \mathrm{~mm}$ copper filter, $500 \mathrm{~ms}$ exposure time, $3.6 \mu \mathrm{m}$ isotropic voxel

400 resolution, 1440 projections over $360^{\circ}$ with three averaged images per rotation position, 401 using a tungsten ("standard") target. The volume reconstructions were performed using the software phoenix datos|x 2 (GE Sensoring \& Inspection Technologies GmbH, Germany).

Three-dimensional reconstruction and nomenclature

405 The annotation was performed onto the $\mu \mathrm{CT}$-based syringeal dataset of a black jacobin adult male. We identified the recognized musculature, ossification, cartilaginous pads, and

407 vibratory tissues. The visualization procedures including volume rendering and manual 
segmentation for surface rendering, and relative quantifications were done with the software

The syrinx structures were defined by the consensus of the microdissection and the

$411 \mu \mathrm{CT}$ data. The nomenclature was given following the same procedure used in Düring et al.

412 (2013) (Table 1). We named the tracheal rings T1 to Tn starting from tympanum and moving

413 toward the larynx. We present a conservative number of intrinsic muscles due to their

414 delineation. We delineated the intrinsic syringeal muscles by aggregating fibers that were

415 oriented at the same angle and defined their differential attachment sites based on both

416 microdissection and the $\mu \mathrm{CT}$ scans. The extrinsic musculature was not traced in the $3 \mathrm{D}$

417 reconstruction due to its undetermined tracheal insertion but is partially shown. The vibratory

418 tissues we found are analogous to those described in Düring et al. (2013).

$420 \quad$ Sound analysis

421 First, we investigated the fundamental frequency of the black jacobin's vocalizations in the wild. Observations and recordings were made in the Professor Mello Leitão Museum (Santa Teresa, Espirito Santo state, Brazil) at a feeding point where every day wild hummingbirds visit feeders that contain $25 \%$ sugar water solution. The observations were made over nine days from November to December 2013, and over 15 days from September to October 2015 during the black jacobin's breeding season (Ruschi, 1964). Black jacobins were observed continuously for one hour a day on the dates mentioned above; observations were made sometime between $6: 30$ and 11 a.m. for a total of approximately 24 hours. The sampling method was ad libitum (Martin and Bateson, 2007), according to which the most conspicuous occurrences of the vocal behavior were recorded for the first black jacobin spotted at the feeding point until the individual had left the place. The black jacobins were not individually 
marked, but the high abundance of the species at the feeding point (Loss and Silva, 2005) and the fact that recordings were obtained over two non-consecutive years make it unlikely that the observations were biased toward a few individuals. Recordings were made 3-10 m from the individuals with a Marantz PMD 671 (Marantz, New York, USA) solid-state recorder connected to a Sennheiser MKH 70/P48 (Sennheiser, Wedemark, Germany) directional microphone in a $48 \mathrm{kHz}$ sampling rate wave file. We obtained 105 recordings totaling five hours. We isolated the black jacobin's vocalizations and calculated the fundamental frequency for each of their syllables (vocal units) using the packages "Seewave" (Sueur et al., 2008) and "WarbleR" (Araya-Salas and Smith-Vidaurre, 2017) in R 3.5.0 (R Core Team, 2018). The recordings are not public due to storage reasons but are available from the corresponding author upon request.

Second, we focused on the most common vocalization of the black jacobin. This vocalization is composed of syllables with continuous and regular fast modulations in fundamental frequency (Olson et al., 2018). Given the periodicity of these modulations, we classified the syllables as vibratos. Vibrato is a demanding vocal task produced by opera singers and characterized by periodic pitch fluctuation (Sundberg, 1994). The accuracy of the vocal performance can be quantified in terms of four parameters: rate, extent, regularity, and waveform (Sundberg, 1994). Here we measured two features of the black jacobin's vibrato: the rate that was measured by the number of oscillations per second and the extent that was the depth of the oscillations. We measured the vibrato based on and adapted from Migita et al. (2010). All calculations were performed on the platform R 3.5.0 (R Core Team, 2018). For the calculations, syllables were selected from full recordings using the package "WarbleR" 454 (Araya-Salas and Smith-Vidaurre, 2017), then the fundamental frequency contour of each unit was identified with "Seewave" (Sueur et al., 2008), and crest-trough pairs were detected using a customized $\mathrm{R}$ script. The vibrato rate given in $\mathrm{Hz}$ was calculated by: 
458 Where Nct is the total number of crest-trough pairs detected per vocal unit, and $\mathrm{T}$ is the total 459 duration of the unit in seconds.

The vibrato extent given in $\mathrm{Hz}$ was obtained per crest-trough pair by the difference between the frequency of the crest and the frequency of the trough. The values were presented as means ( \pm standard deviation, sample size).

We analyzed three high-quality sound recordings and 18 syllables with the highest quality obtained from three black jacobins. These recordings were kindly provided by Olson $250 \mathrm{kHz}$ range) coupled to an UltraSoundGate $416 \mathrm{H}$ amplifier recorder at the frequency rate of $214 \mathrm{kHz}$. To have something to compare with the black jacobin, we analyzed the soundtrack "I will always love you" performed by Whitney Houston (C Sony Music, 1992) and selected 12 fragments in which the singer produces a vibrato as an example of a human singer. As an example of a vibrato produced by a songbird, we analyzed two recordings of the Eurasian skylark (Alauda arvensis) obtained from the Xeno-canto collaborative bird sound collection (https://www.xeno-canto.org/), catalog numbers XC401962 and XC417772 uploaded by Karl-Birger Strann and Jarek Matusiak, respectively. The vibrato examples of both the human singer and songbird were analyzed following the same parameters as the black jacobin recordings.

\section{Acknowledgments}

477 We are grateful to the staff of the Museu de Biologia Professor "Mello Leitao" (current 
479 the former director Hélio de Queiroz Boudet Fernandes for logistical support. We thank

480 Christopher Olson for providing high-quality sound recordings of the black jacobin. AM

481 received an IMPRS Organismal Biology grant for language editing; we thank E. Wheeler for

482 the helpful comments.

\section{Authors' contributions}

485

486

487

488

AM and DD conceived the study. AM, AC, BR, and DD contributed to data acquisition. DD, $\mathrm{AC}, \mathrm{BH}$, and $\mathrm{MG}$ contributed reagents, materials, and analytical tools. All authors contributed to data analysis. AM wrote the initial draft of the manuscript. All authors contributed to manuscript revision and approved the final version.

\section{References}

Amador A, Mindlin GB. 2008. Beyond harmonic sounds in a simple model for birdsong production. Chaos 18:043123. doi:10.1063/1.3041023

Ames PL. 1971. The Morphology of the Syrinx in Passerine Birds - Peter L. Ames - Google Books, Peabody Museum of Natural History, Yale University. ed, Bulletin 37. Chicago, Illinois.

Araya-Salas M, Smith-Vidaurre G. 2017. warbleR: an r package to streamline analysis of animal acoustic signals.

Baptista LF, Schuchmann K-L. 1990. Song Learning in the Anna Hummingbird (Calypte anna). Ethology 84:15-26. doi:10.1111/j.1439-0310.1990.tb00781.x

Beddard FE. 1898. The structure and classification of birds. London, New York and Bombay: Longmans, Green, and co.

Berthaume MA, Federico ED, Bull AMJ. 2019. Fabella prevalence rate increases over 150 years, and rates of other sesamoid bones remain constant: a systematic review. Journal of Anatomy 235:67-79. doi:10.1111/joa.12994

Bottjer SW, Glaessner SL, Arnold AP. 1985. Ontogeny of brain nuclei controlling song learning and behavior in zebra finches. $J$ Neurosci 5:1556-1562. doi:10.1523/JNEUROSCI.05-06-01556.1985

Clarke JA, Chatterjee S, Li Z, Riede T, Agnolin F, Goller F, Isasi MP, Martinioni DR, Mussel FJ, Novas FE. 2016. Fossil evidence of the avian vocal organ from the Mesozoic. Nature 538:502.

Duque FG, Rodríguez-Saltos CA, Wilczynski W. 2018. High-frequency vocalizations in Andean hummingbirds. Curr Biol 28:R927-R928. doi:10.1016/j.cub.2018.07.058 
Düring DN, Elemans CPH. 2016. Embodied Motor Control of Avian Vocal ProductionVertebrate Sound Production and Acoustic Communication. Springer, Cham. pp. 119-157.

Düring DN, Knörlein BJ, Elemans CPH. 2017. In situ vocal fold properties and pitch prediction by dynamic actuation of the songbird syrinx. Sci Rep 7:11296.

Düring Daniel N., Ziegler Alexander, Thompson CK, Ziegler Andreas, Faber C, Müller J, Scharff C, Elemans CPH. 2013. The songbird syrinx morphome: a three-dimensional, high-resolution, interactive morphological map of the zebra finch vocal organ. $B M C$ Biol 11:1. doi:10.1186/1741-7007-11-1

Elemans CPH, Mead AF, Rome LC, Goller F. 2008. Superfast Vocal Muscles Control Song Production in Songbirds. PLOS ONE 3:e2581. doi:10.1371/journal.pone.0002581

Elemans CPH, Rasmussen JH, Herbst CT, Düring DN, Zollinger SA, Brumm H, Srivastava K, Svane N, Ding M, Larsen ON, Sober SJ, Švec JG. 2015. Universal mechanisms of sound production and control in birds and mammals. Nature Communications 6:8978.

Elemans CPH, Spierts ILY, Müller UK, Leeuwen JL van, Goller F. 2004. Superfast muscles control dove's trill. Nature 431:146. doi:10.1038/431146a

Ferreira ARJ, Smulders TV, Sameshima K, Mello CV, Jarvis ED. 2006. Vocalizations and associated behaviors of the Sombre Hummingbird (Aphantochroa cirrhochloris) and the Rufous-Breasted Hermit (Glaucis hirsutus). Auk 123:1129-1148.

Ficken MS, Rusch KM, Taylor SJ, Powers DR. 2000. Blue-Throated Hummingbird song: a pinacle of nonoscine vocalizations. The Auk 117:120-128. doi:10.1642/00048038(2000)117[0120:BTHSAP]2.0.CO;2

Gaban-Lima R, Höfling E. 2006. Comparative anatomy of the syrinx in the Tribe Arini (Aves: Psittacidae). Braz J morphol Sci 23:501-512.

Gahr M. 2000. Neural song control system of hummingbirds: comparison to swifts, vocal learning (Songbirds) and nonlearning (Suboscines) passerines, and vocal learning (Budgerigars) and nonlearning (Dove, owl, gull, quail, chicken) nonpasserines. $J$ Comp Neurol 426:182-196.

Gaunt AS. 1983. An Hypothesis concerning the Relationship of Syringeal Structure to Vocal Abilities. The Auk 100:853-862.

Gaunt AS, Gaunt SLL. 1985. Syringeal Structure and Avian PhonationCurrent Ornithology. New York: Plenum Press. pp. 213-245.

Goller F, Riede T. 2013. Integrative physiology of fundamental frequency control in birds. $J$ Physiol Paris 107:230-242. doi:10.1016/j.jphysparis.2012.11.001

Jarvis ED. 2007. Neural systems for vocal learning in birds and humans: a synopsis. $J$ Ornithol 148:35-44. doi:10.1007/s10336-007-0243-0

Jarvis ED. 2006. Selection for and against vocal learning in birds and mammals. jorn 5:5-15. doi:10.2326/osj.5.5

Jarvis ED, Mello CV. 2000. Molecular mapping of brain areas involved in parrot vocal communication. J Comp Neurol 419:1-31.

King AS. 1989. Functional anatomy of the syrinx. Form and Function in Birds. New York and London: Academic Press.

Loss ACC, Silva AG. 2005. Comportamento de forrageio de aves nectarívoras de Santa Teresa - ES. Natureza on line 2:48-52.

Marler P. 1970. Birdsong and Speech Development: Could There Be Parallels? There may be basic rules governing vocal learning to which many species conform, including man. American Scientist 58:669-673.

Martin P, Bateson P. 2007. Measuring Behaviour: An Introductory Guide, 3rd ed. Cambridge University Press. doi:10.1017/CBO9780511810893 
McGuire JA, Witt CC, Remsen Jr. JV, Corl A, Rabosky DL, Altshuler DL, Dudley R. 2014. Molecular Phylogenetics and the Diversification of Hummingbirds. Current Biology 24:1-7. doi:10.1016/j.cub.2014.03.016

Migita N, Morise M, Nishiura T. 2010. A Study of Vibrato Features to Control Singing VoicesProceedings of 20th International Congress on Acoustics, ICA 2010. Sydney, Australia.

Mindlin GB, Laje R. 2006. The Physics of Birdsong. Springer Science \& Business Media.

Müller JP. 1878. On certain variations in the vocal organs of the Passeres that have hitherto escaped notice. Oxford, Clarendon Press.

Mundinger PC. 1995. Behaviour-genetic analysis of canary song: inter-strain differences in sensory learning, and epigenetic rules. Animal Behaviour 50:1491-1511. doi:10.1016/0003-3472(95)80006-9

Nottebohm F. 1976. Phonation in the Orange-winged Amazon parrot,Amazona amazonica. $J$ Comp Physiol 108:157-170. doi:10.1007/BF02169046

Nottebohm F, Stokes TM, Leonard CM. 1976. Central control of song in the canary, Serinus canarius. J Comp Neurol 165:457-486. doi:10.1002/cne.901650405

Nowicki S, Searcy WA. 2014. The evolution of vocal learning. Current Opinion in Neurobiology 28:48-53. doi:10.1016/j.conb.2014.06.007

Olson CR, Fernández-Vargas M, Portfors CV, Mello CV. 2018. Black Jacobin hummingbirds vocalize above the known hearing range of birds. Current Biology 28:R204-R205. doi:10.1016/j.cub.2018.01.041

Paton J, Manogue K, Nottebohm F. 1981. Bilateral organization of the vocal control pathway in the budgerigar, Melopsittacus undulatus. $J$ Neurosci 1:1279. doi:10.1523/JNEUROSCI.01-11-01279.1981

Prum RO, Berv JS, Dornburg A, Field DJ, Townsend JP, Lemmon EM, Lemmon AR. 2015. A comprehensive phylogeny of birds (Aves) using targeted next-generation DNA sequencing. Nature 526:569.

R Core Team. 2018. R: A Language and Environment for Statistical Computing. Vienna, Austria: R Foundation for Statistical Computing.

Riede T, Fisher JH, Goller F. 2010. Sexual Dimorphism of the Zebra Finch Syrinx Indicates Adaptation for High Fundamental Frequencies in Males. PLOS ONE 5:e11368. doi:10.1371/journal.pone.0011368

Riede T, Thomson SL, Titze IR, Goller F. 2019. The evolution of the syrinx: An acoustic theory. PLOS Biology 17:e2006507. doi:10.1371/journal.pbio.2006507

Rome LC. 2006. Design and function of superfast muscles: new insights into the physiology of skeletal muscle. Annu Rev Physiol 68:193-221.

Rome LC, Syme DA, Hollingworth S, Lindstedt SL, Baylor SM. 1996. The whistle and the rattle: the design of sound producing muscles. Proc Natl Acad Sci U S A 93:80958100.

Ruschi A. 1964. A estação ou o período de reprodução nos beija-flores. Boletim do Museu de Biologia Prof Mello Leitão 42.

Ruschi PA. 2009. A new hummingbird trap. Boletim do Museu de Biologia Prof Mello Leitão 25:67-75.

Schuchmann KL. 1999. Family Trochilidae (Hummingbirds) In: del Hoyo J, Elliott A, Sargatal J, editors. Handbook of the Biords of the World. Vol. 5. Barn-Owls to Hummingbirds. Barcelona: Lynx Edicions. pp. 34-75.

Smolker RE. 1947. The Avian syrinx, its use in classification. (Master). Boston University.

Sueur J, Aubin T, Simonis C. 2008. Seewave, a Free Modular Tool for Sound Analysis and Synthesis. Bioacoustics 18:213-226. doi:10.1080/09524622.2008.9753600 
610 Sundberg J. 1994. Acoustic and Psychoacoustic Aspects of Vocal Vibrato. STL-QPSR 35:4561168.

612 Suthers RA. 2004. Chapter 9 - How birds sing and why it matters In: Marler P, Slabbekoorn 613 H, editors. Nature's Music. San Diego: Academic Press. pp. 272-295. doi:10.1016/B978-012473070-0/50012-8

616

Suthers RA, Zollinger SA. 2008. From brain to song: the vocal organ and vocal tract In: Zeigler HP, Marler P, editors. Neuroscience of Birdsong. Cambridge University Press. pp. 78-98.

Titze IR. 1992. Phonation threshold pressure: A missing link in glottal aerodynamics. The Journal of the Acoustical Society of America 91:2926-2935. doi:10.1121/1.402928

621

622

623

624

625

Williams BR, Houtman AM. 2008. Song of Costa's Hummingbird (Calypte Costae). The Auk 125:663-669. doi:10.1525/auk.2008.07058

Zusi Richard L. 2013. Introduction to the Skeleton of Hummingbirds (Aves: Apodiformes, Trochilidae) in Functional and Phylogenetic ContextsOrnithological Monographs No. 77, Ornithological Monographs. American Ornithologists' Union. pp. 1-94. doi:10.1525/om.2013.77.1.1 
bioRxiv preprint doi: https://doi.org/10.1101/2020.01.11.902734; this version posted January 13, 2020. The copyright holder for 2 (19S

preprint (which was not certified by peer review) is the author/funder. All rights reserved. No reuse allowed without permission.

\section{$627 \quad$ Figures}

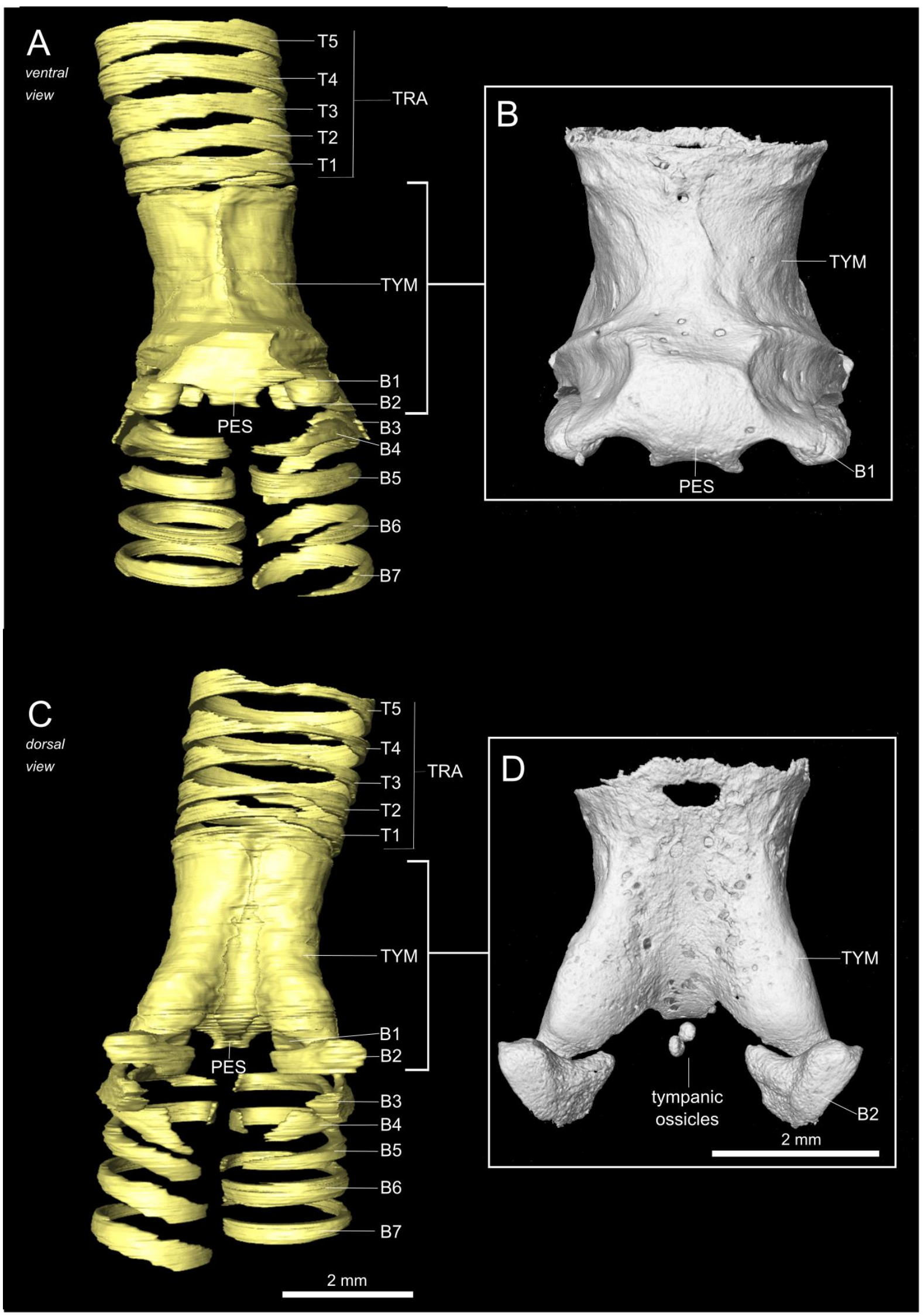


629 Fig 1 - The syringeal skeleton of the black jacobin. 3D visualizations of $\mu \mathrm{CT}$ data. A and $\mathrm{C}$,

630 surface renderings of the contrasted sample; B and D, volume renderings of the non-

631 contrasted sample. A and B, ventral view; C and D, dorsal view. In D, the tympanic ossicles

632 can be seen. T1 to T5, tracheal rings; TYM, tympanum; B1 to B7, bronchial half-rings and

633 PES, pessulus. 
bioRxiv preprint doi: https://doi.org/10.1101/2020.01.11.902734; this version posted January 13, 2020. The copyright holder for 21 出S preprint (which was not certified by peer review) is the author/funder. All rights reserved. No reuse allowed without permission.

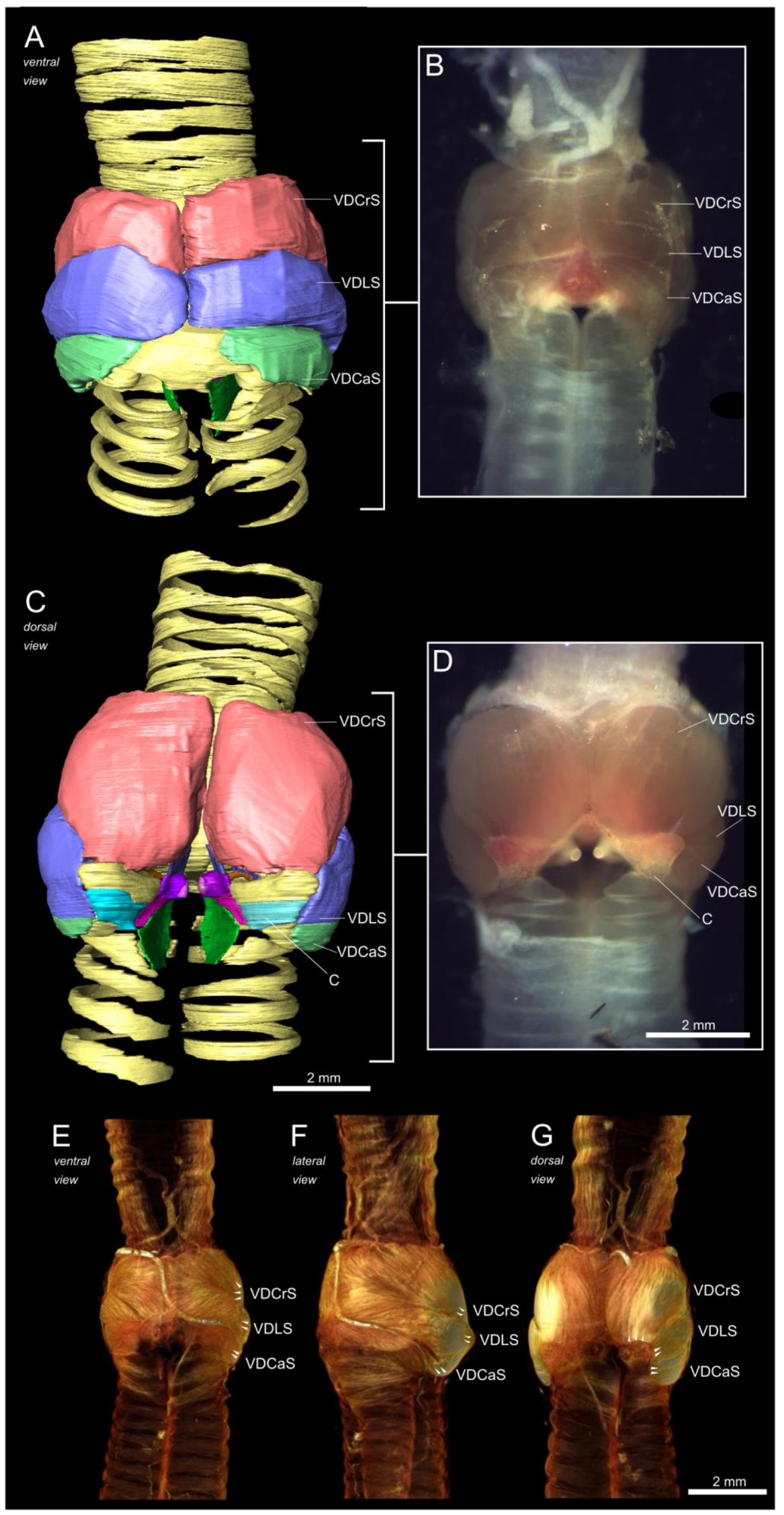


bioRxiv preprint doi: https://doi.org/10.1101/2020.01.11.902734; this version posted January 13,2020 . The copyright holder for $29 \mathrm{AS}_{\mathrm{S}}$ preprint (which was not certified by peer review) is the author/funder. All rights reserved. No reuse allowed without permission.

635 Fig 2 - Musculature of the black jacobin's syrinx. A and C, surface renderings; B and D, in

636 vitro syrinx and $\mathrm{E}, \mathrm{F}$ and $\mathrm{G}$, volume renderings. $\mathrm{A}, \mathrm{B}$ and $\mathrm{E}$, ventral view; $\mathrm{C}, \mathrm{D}$ and $\mathrm{G}$, dorsal

637 view and F, lateral view. The arrows indicate the orientation of the fibers. VDCrS, ventro-

638 dorsal cranial syringeal muscle; VDLS, ventro-dorsal lateral syringeal muscle; VDCaS,

639 ventro-dorsal caudal syringeal muscle and C, cartilage.

640

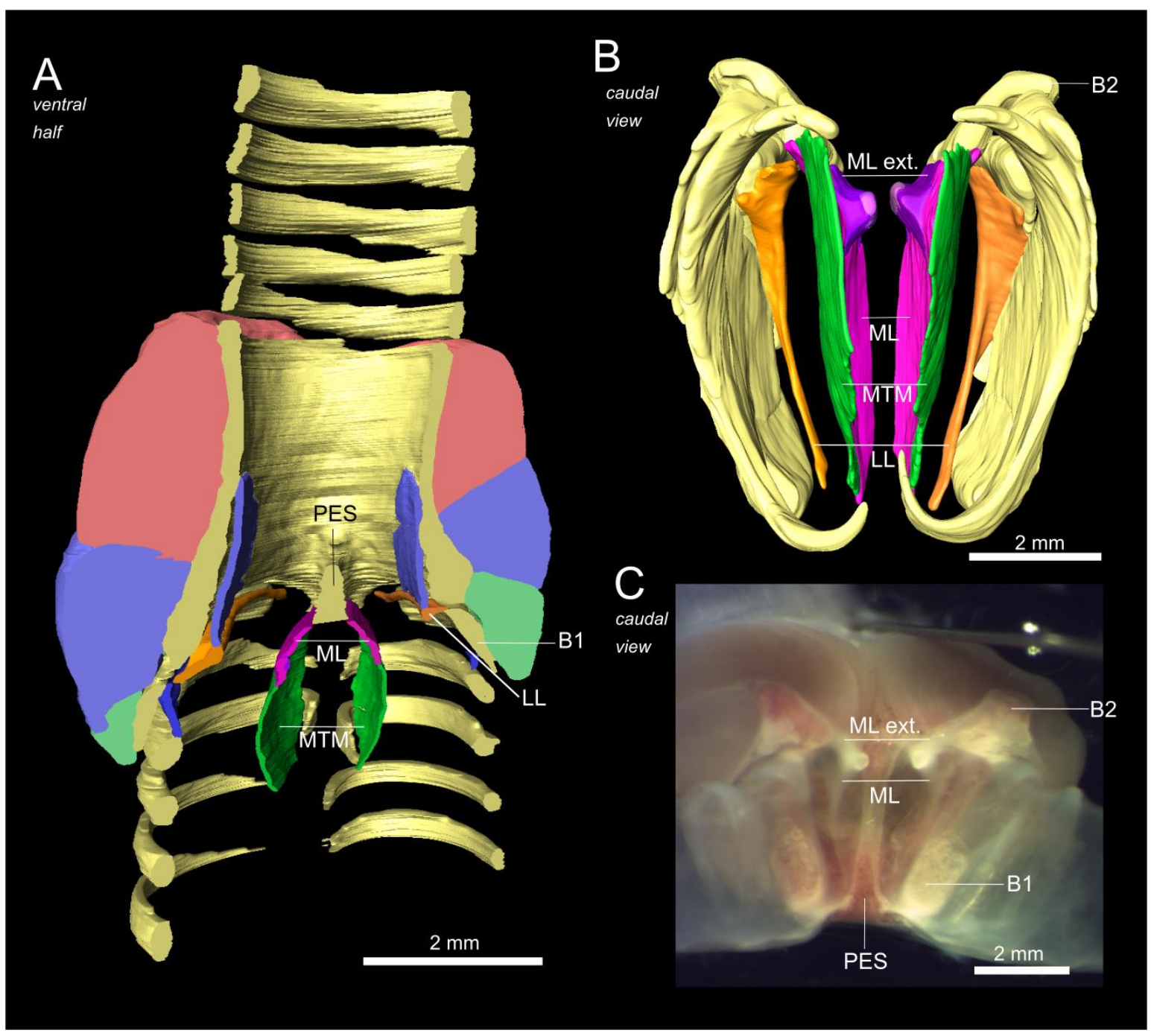

642 Fig 3 - Vibratory membranes of the black jacobin's syrinx. A and B, surface renderings and

$643 \mathrm{C}$, in vitro syrinx. A, ventral view and $\mathrm{B}$ and $\mathrm{C}$, caudal view. In $\mathrm{B}$, the first three pairs of

644 bronchial half-rings and all pairs of vibratory membranes: LL (orange), MTM (green), ML 
645 (pink), ML extension (purple). PES, pessulus; ML, medial labium; MTM, medial 646 tympaniform membrane; LL, lateral labium; B1, first bronchial half-ring; B2, second 647 bronchial half-ring and ML ext., the cartilaginous extension of the ML.

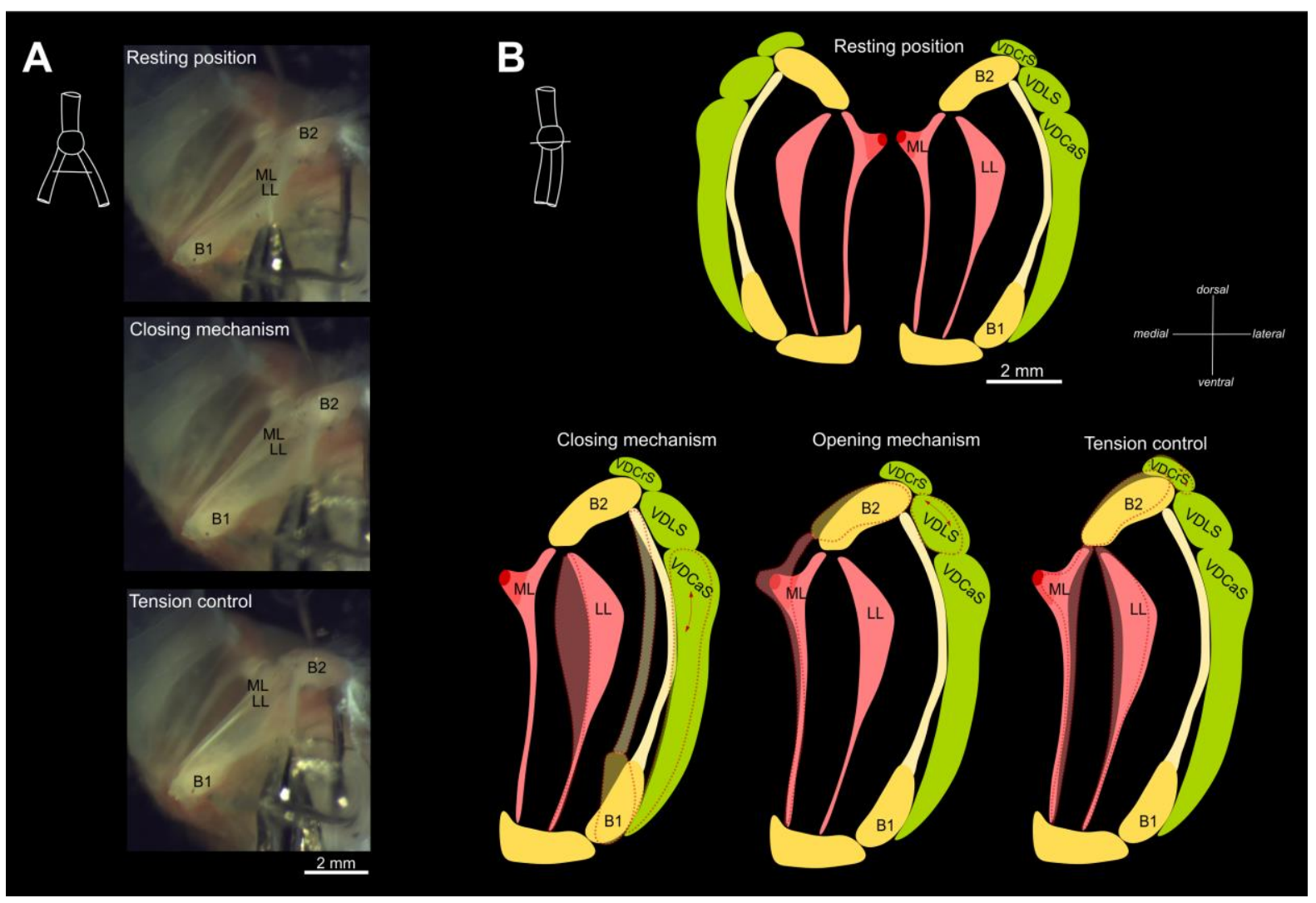

650 Fig. 4 - Biomechanics of the black jacobin's syrinx. In A, caudal view in vitro. Upper panel:

651 resting position; middle panel: inwards movement of the LL for abduction of the labia; lower

652 panel: stiffening of the ML for tension control. In B, schematic representation of the syrinx,

653 cranial view. Top: resting condition; bottom: closing, opening and tension control through

654 hypothetical VDCaS, VDLS or VDCrS contraction. The shaded areas indicate the position of

655 the syrinx in relation to the resting position and the red arrows indicate the involved muscle.

656 ML, medial labium; MTM, medial tympaniform membrane; LL, lateral labium; B1, first

657 bronchial half-ring; B2, second bronchial half-ring; ML, medial labia; LL lateral labia; 
658 VDCrS, ventro-dorsal cranial syringeal muscle; VDLS, ventro-dorsal lateral syringeal muscle; VDCaS, ventro-dorsal caudal syringeal muscle.
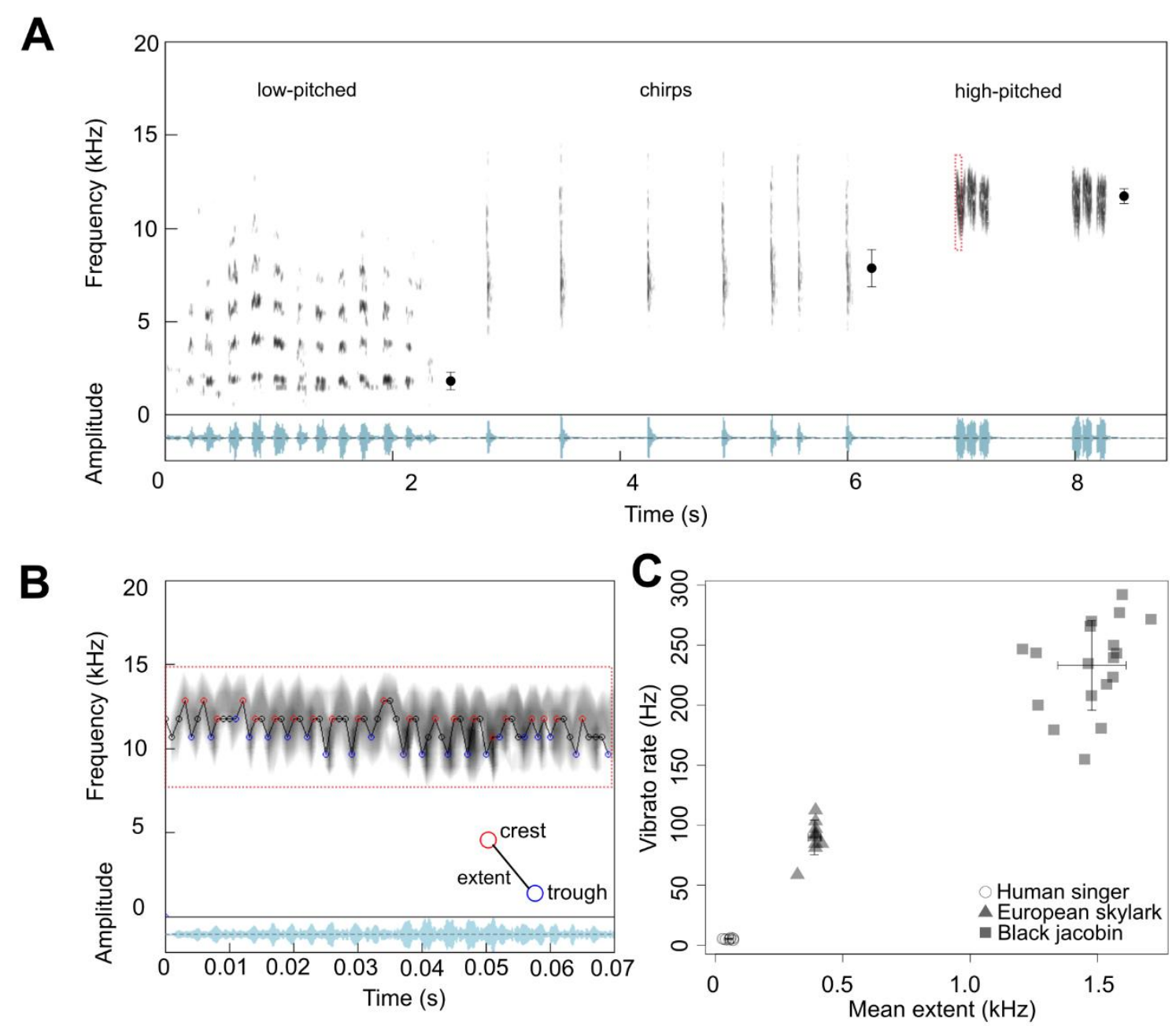

660

661 Fig. 5 - Black jacobin vocalizes in a wide frequency range with rapidly modulated vibratos.

662 In A, spectrogram (frequency) and oscillogram (amplitude) of the three vocalization types

663 produced by the black jacobin in the wild: low-pitched, chirps and high-pitched. The dots

664 represent the average fundamental frequency for the respective vocalization on their left, and

665 the whisker, the standard deviation. In B, an example of crest-trough detection in the high-

666 pitched fragment is indicated by the box with red dashes in A obtained by our customized R

667 function. Red circles indicate the crest, and blue the trough; the difference between them is

668 the vibrato extent. In $\mathrm{C}$, the vibrato rate is calculated as the number of crest and trough pairs 
669 per second given in $\mathrm{Hz}$, and the mean extent for each syllable/segment is calculated in $\mathrm{kHz}$.

670 The cross indicates means and arrows the standard deviation. Triangles represent the data

671 points obtained by an example of vibrato produced by a human singer $(\mathrm{n}=12$ vibrato

672 segments in one song), the squares represent data points for the black jacobin $(\mathrm{n}=18$

673 syllables from three birds), circles for Eurasian skylark (Alauda arvensis) $(\mathrm{n}=11$ syllables

674 from two birds). See the Methods for the source of the sound recordings.

676 Table 1 - Anatomical structures of the black jacobin syrinxes described in this study. The

677 source indicates when the name is given in analogy with a previous description for a different

678 species

\begin{tabular}{|c|c|c|c|c|c|}
\hline English term & Abbreviation & Latin term & Source & $\begin{array}{l}\text { Brief anatomical } \\
\text { description }\end{array}$ & Figure(s) \\
\hline lateral labium & LL & labium laterale & $\begin{array}{l}\text { (Düring } \\
\text { et al., } \\
2013)\end{array}$ & $\begin{array}{l}\text { Paired soft tissue. } \\
\text { Projects from between } \\
\text { the caudal tympanum } \\
\text { and half-ring B1 into } \\
\text { the syrinx air passage. }\end{array}$ & Fig. 3A \\
\hline medial labium & ML & labium mediale & $\begin{array}{l}\text { (Düring } \\
\text { et al., } \\
\text { 2013) }\end{array}$ & $\begin{array}{l}\text { Paired soft tissue. } \\
\text { Projects from the } \\
\text { medial part of the } \\
\text { syrinx into the air } \\
\text { passage. } \\
\text { Forms a tissue } \\
\text { continuum with the } \\
\text { medial tympaniform } \\
\text { membrane. }\end{array}$ & Fig. 3A \\
\hline $\begin{array}{l}\text { medial } \\
\text { tympaniform } \\
\text { membrane }\end{array}$ & MTM & $\begin{array}{l}\text { membrana } \\
\text { tympaniformis } \\
\text { medialis }\end{array}$ & $\begin{array}{l}\text { (Düring } \\
\text { et al., } \\
\text { 2013) }\end{array}$ & $\begin{array}{l}\text { Paired connective } \\
\text { tissue element. } \\
\text { Suspended between the } \\
\text { ventro-dorsal } \\
\text { extremities of the } \\
\text { bronchial half-rings B1 } \\
\text { and B3. } \\
\text { Forms a tissue } \\
\text { continuum with the } \\
\text { medial labium. }\end{array}$ & Fig. 3A \\
\hline
\end{tabular}




\begin{tabular}{|l|l|l|l|l|l|}
\hline $\begin{array}{l}\text { tracheolateral } \\
\text { muscle }\end{array}$ & TL & $\begin{array}{l}\text { musculus } \\
\text { tracheolateralis }\end{array}$ & $\begin{array}{l}\text { (Düring } \\
\text { et a., } \\
\text { 2013) }\end{array}$ & $\begin{array}{l}\text { Paired muscle. Forms } \\
\text { an extended band } \\
\text { along the trachea. } \\
\text { Attaches caudally to } \\
\text { the syrinx and cranially } \\
\text { to the larynx. }\end{array}$ & $\begin{array}{l}\text { Fig. 2E- } \\
\text { G }\end{array}$ \\
\hline $\begin{array}{l}\text { ventro-dorsal } \\
\text { cranial } \\
\text { syringeal } \\
\text { muscle }\end{array}$ & VDCrS & $\begin{array}{l}\text { musculus } \\
\text { syringealis } \\
\text { cranialis dorsalis } \\
\text { ventralis }\end{array}$ & $\begin{array}{l}\text { present } \\
\text { study }\end{array}$ & $\begin{array}{l}\text { Paired muscle. } \\
\text { Attaches to tympanum } \\
\text { and the cranial part of } \\
\text { the half-ring B2. }\end{array}$ & Fig. 2 \\
\hline $\begin{array}{l}\text { ventro-dorsal } \\
\text { lateral } \\
\text { syringeal } \\
\text { muscle }\end{array}$ & VDLS & $\begin{array}{l}\text { musculus } \\
\text { syringealis } \\
\text { lateralis dorsalis } \\
\text { ventralis }\end{array}$ & $\begin{array}{l}\text { present } \\
\text { study }\end{array}$ & $\begin{array}{l}\text { Paired muscle. } \\
\text { Attaches to tympanum } \\
\text { and the lateral part of } \\
\text { the half-ring B2. }\end{array}$ & Fig. 2 \\
\hline $\begin{array}{l}\text { ventro-dorsal } \\
\text { caudal } \\
\text { syringeal } \\
\text { muscle }\end{array}$ & VDCaS & $\begin{array}{l}\text { musculus } \\
\text { syringealis } \\
\text { caudalis dorsalis } \\
\text { ventralis }\end{array}$ & $\begin{array}{l}\text { present } \\
\text { study }\end{array}$ & $\begin{array}{l}\text { Paired muscle. } \\
\text { Attaches to tympanum } \\
\text { and the lateral part of } \\
\text { the half-ring B1. }\end{array}$ & Fig. 2 \\
\hline
\end{tabular}

